\title{
Cell sheets in cell therapies
}

Giles T.S Kirby ${ }^{1,2}$, Andrew Michelmore ${ }^{1,2,3}$, Louise E. Smith ${ }^{1,2}$, Jason D. Whittle ${ }^{1,2,3}$, Robert D. Short ${ }^{1,2,4}$

1 Future Industries Institute, University of South Australia, Mawson Lakes, Adelaide, South Australia 5095.

2 Cooperative Research Centre for Cell Therapy Manufacturing, University of South Australia, Adelaide, South Australia 5000, Australia.

3 School of Engineering, University of South Australia, Mawson Lakes, Adelaide, SA 5095

4 Materials Science Institute and Department of Chemistry, University of Lancaster, City of Lancaster, UK

Keywords: Culture; sheet; therapy; regeneration; plasma polymerization.

\section{Abstract}

This review aims to provide a broad introduction to the use of cell sheets and the role of materials in the delivery of cell sheets to patients within a clinical setting. Traditionally, cells sheets have been / are fabricated using established and accepted cell culture methods within standard formats (e.g. petri dishes) utilising biological substrates. Synthetic surfaces provide a far more versatile system for culturing and delivering cell sheets. This has the potential to positively impact quality, and efficient, localised, cell delivery has a significant impact on patient outcome and on the overall cost of goods (COG's). We highlight current applications of these advanced carriers and future applications of these surfaces and cell sheets with an emphasis both on clinical use and regulatory requirements.

\section{Introduction - Why cell sheets}

Cell therapies (CT) have historically been delivered by injection, transfusion or direct application, with the cells of interest in suspension. One of the first cell therapy approaches reported in the literature was a transfusion of sheep blood into a human in 1667 [1]. Later examples include in the nineteenth century when Charles-Edouard Brown-Sequard injected rat testicle extract into humans, attempting to stop aging [2]. While some of these early 
interventions were of dubious merit, in 1968 the first successful bone marrow transplant was conducted [3]. In recent years' cell therapy has evolved rapidly to the point where there are many cell types of interest for a wide range of indications [4], however these delivery routes have limitations, namely a lack of control as to where the cells go and a non-homogeneous distribution of the cells within the treated area. Injection and transfusion are not necessarily best suited where localised delivery is necessitated. Therefore biomaterials are significant as delivery devices for cell therapies [5].

The human body is full of planar membranes such as the skin, oesophagus, uterus and bladder. For example, skin, as the largest organ in the body and the most accessible tissue, has been the subject of some of the earliest interventions. Skin grafting is thought to have originated in India approximately 2500 to 3000 years ago [6] with the concept gradually migrating into Western medicine. Bunger, a German physician, reported the successful transfer of skin from the buttock to the nose in 1869 [7] and in 1875, Wolfe reported the first full thickness skin graft [8]. Many of these planar surfaces are difficult, if not impossible to treat effectively with cell suspensions. Furthermore, the importance of cell-cell interactions may be critical to efficacy and modes of action, but as soon as adherent cells are placed into a suspension, this behaviour is compromised, potentially effecting viability and function. Cell sheets negate this risk and in some cases, may be used to deliver a denser cell population to the required site. By integrating the process of expansion, storage, transportation and clinical cell delivery, it would be possible to get the cell product to the patient more quickly, negating the risks associated with dense cell populations (loss of phenotype/differentiation).

A well tested method for delivery of cell therapies to wound sites is outlined in Figure 1, demonstrating the extraction of healthy cells from the patient, their expansion in vitro, and delivery to the wound site. This review focuses simply on planar surfaces for the delivery of cell monolayers and the application of materials science to optimise patient outcomes. In this review, we are defining cell sheets as cells that are either self-supporting or delivered from a supporting material, but where the material plays no long-term role in the therapy. Cell sheets can be single or multiple layered, and even sub-confluent in some cases. Various culture and release methods are used to generate cell sheets; perhaps most common is dispase (or other enzymatic) treatment [9], other more exotic methods include thermo responsive polymers [10], a range of inorganic complexes that respond to magnetic force [11], electrochemical 
polarisation [12] and $\mathrm{pH}$ change [13]. However, each of these technologies relies upon multiple steps and a high degree of manual handling or automation [14].

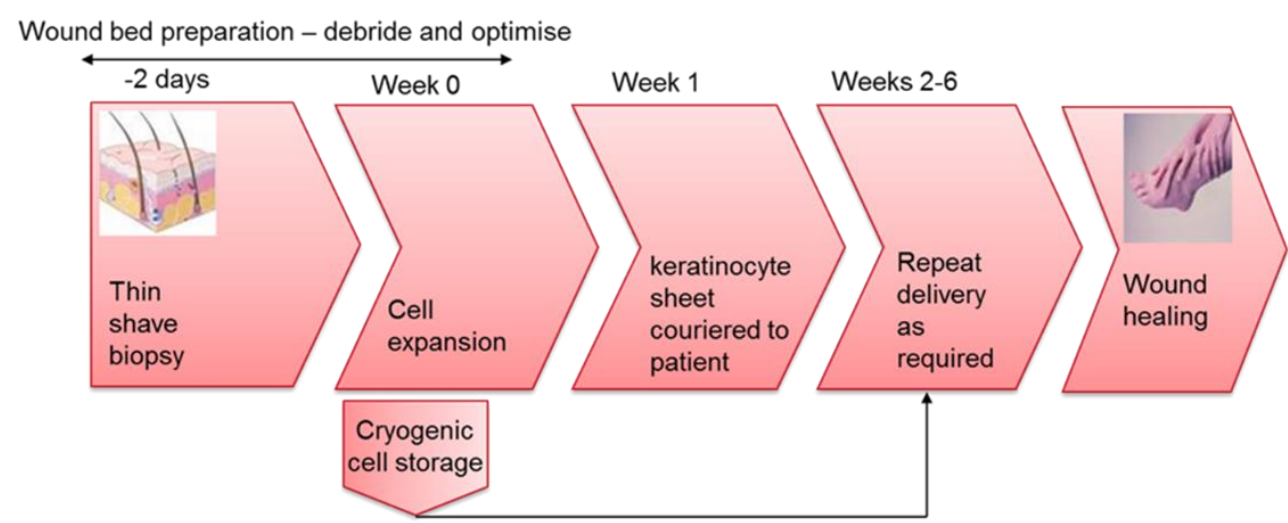

Figure 1. Simplified steps in the delivery of autologous cell therapies for wound healing.

Society is on the cusp of a cell therapy (CT) medical revolution however there are numerous challenges to overcome to deliver on the promise of CT. The quote (often attributed to Albert Einstein): "Make things as simple as possible, but not simpler" is a good philosophy for the development of cheap and effective clinical cell therapies, and there is a growing body of evidence suggesting that certain clinical indications are most suited to the delivery of 2-D monolayer/multi-layer of adherent cells or sheets of cells. This includes resurfacing lost epithelial tissue [15], the cornea [16], oesophageal [17], bladder [18], retinal [19, 20], tracheal [21], uterine [22] and myocardial [23].

Whilst the approach of using cell sheets is highly suited to autologous cell therapy, there is a corresponding effort to develop allogeneic (and cryopreserved) cell sheets [24]. A review for cell sheet development and emerging cell sheet technologies and applications is timely given the high academic and commercial interest in cell sheets.

The value of cell sheets has been identified commercially and multiple companies are beginning to provide cell sheet products (Table 1).

Table 1. Commercial entities that have invested in the future of cell sheets.

\begin{tabular}{|c|c|c|}
\hline Company & Product(s) & Brief description \\
\hline 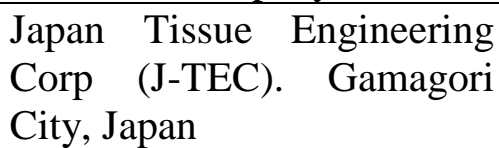 & $\begin{array}{l}\text { Autologous cultured } \\
\text { epidermis }\end{array}$ & Cultured epidermal autograft \\
\hline
\end{tabular}




\begin{tabular}{|c|c|c|}
\hline $\begin{array}{l}\text { Japan Tissue } \text { Engineering } \\
\text { Corp (J-TEC). Gamagori } \\
\text { City, Japan }\end{array}$ & $\begin{array}{l}\text { Autologous cultured } \\
\text { corneal epithelium }\end{array}$ & $\begin{array}{l}\text { Autologous corneal epithelial cells } \\
\text { cultured on hydrogel. }\end{array}$ \\
\hline CellSeed inc.. Tokyo, Japan & UpCell@ RepCell@ & $\begin{array}{l}\text { Cultureware based on the Poly }(\mathrm{N}- \\
\text { isopropylacrylamide) } \\
\text { responsive polymer }\end{array}$ \\
\hline Vericel. MI, USA & Epicel & Cultured epidermal autograft \\
\hline $\begin{array}{l}\text { Modex } \quad \text { Therapeutics. } \\
\text { Lausanne, Switzerland }\end{array}$ & Epidex & $\begin{array}{l}\text { Autologous follicle keratinocytes } \\
\text { attached to a silicone sheet (with } 1 \% \\
\text { agarose). }\end{array}$ \\
\hline $\begin{array}{l}\text { Organogenesis inc. MA, } \\
\text { USA }\end{array}$ & Apligraf® & $\begin{array}{l}\text { Bovine collagen and fibroblasts } \\
\text { topped with keratinocytes }\end{array}$ \\
\hline $\begin{array}{l}\text { Organogenesis inc. MA, } \\
\text { USA }\end{array}$ & Dermagraft $®$ & polyglactin mesh with keratinocytes \\
\hline
\end{tabular}

3. Historical development of biological substrates

Modern clinical use of intact cell sheets is built upon the foundations of cell culture. The use of cultured autologous keratinocytes to treat burns is now a well-established clinical procedure [25-27]. The earliest confluent cell sheet therapies were developed as an extension to skin grafts for the treatment of extensive burns [28]. Those that demonstrated long-term effectiveness, utilise autologous keratinocytes [29-35] and were based upon (at the time) pioneering cell culture techniques. In 1975, James Reinwald, Ph.D. and Howard Green, M.D. (Rheinwald and Green) first demonstrated the isolation and serial culture of human epidermal keratinocytes in vitro with lethally irradiated mouse fibroblasts as a feeder layer [36]. Soon after, this process was used to produce large sheets of cultured epithelium suitable for grafting. Such cultured epithelial autografts (CEAs) were first used in the treatment of major burns in 1981 [37]. The basic procedure comprises taking an unaffected patient skin sample of a few $\mathrm{cm}^{2}$ under local anaesthesia. The biopsy is stored in culture media and after removal of the dermis and other non-epidermal material, the sample is minced and treated with trypsin. Seeding density varies according to the original amount of material available, but is in the range of $10^{4}$ to $10^{6}$ per dish $(50 \mathrm{~mm})$ and is carried out on lethally irradiated $3 \mathrm{~T} 3$ fibroblasts. The media is supplemented with serum and growth factors and changed twice weekly. Over a period of 14 -21 days, a confluent sheet forms which is then detached from the cultureware with dispase. It is reported that sheets shrink in size at this stage [37]. Sheets are washed with serum-free medium and placed basal side up on a double layered "Vaseline" gauze and then transported to the patient 
in a glass jar flushed with $10 \% \mathrm{CO}_{2}$ and sealed. In the $\mathrm{R} \& \mathrm{G}$ method, the grafts on vaseline gauze are placed on the prepared sites, with the basal cell layer directed against the wound. Suturing is unnecessary and a single layer of non-impregnated fine mesh gauze and a loose layer of coarse mesh gauze, which is changed daily, held the grafts in place. Between day 6 and 10, the fine mesh gauze and the vaseline gauze are usually removed and the area redressed with a single layer of vaseline gauze and a loose layer of coarse gauze. These dressings are then changed daily for 3-4 weeks from the time of grafting.

CEAs have been used successfully since 1980 as a permanent coverage for large full-thickness burn wounds [9, 37-40]. This revolutionary cell therapy addressed the problem of severe burns, extending over $30 \%$ (or more) of the body - where simply there is not enough unaffected to tissue to graft.

This general approach to the production of free standing cell sheets has been adapted to a range of other indications, whereby free-standing cell sheets are produced in cell culture, removed by enzymes and delivered to the patient on a separate backing material. An example includes corneal cells for the treatment of trauma and diseases such as limbal stem cell deficiency (LSCD). Corneal cells are expanded upon a range of materials i.e. tissue culture plastic [41], murine feeder cells [42], and collagen [43].

De-Epidermised dermis (DED) is widely available from the European skin bank in a highly characterised, stable form and preparation methods for DED as a support material for keratinocytes and fibroblasts go back over a decade [44]. This material has been used for the development of tissue engineered, or reconstructed, skin products consisting of expanded autologous keratinocytes and fibroblasts with the aim of improving healing after burns [45-49]. This approach has been further developed to include oral keratinocytes and fibroblasts for treatment of oral defects [49, 50] and urethral structures [51, 52]. More sophisticated approaches embrace the inclusion of endothelial cells to increase defect vascularisation [53], a significant problem in more substantial implants/grafts.[53]

The major protein component of the dermis is collagen 1, so it is not surprising that collagen has been used in a variety of tissue engineering applications, including skin [54, 55]. There is a wide range of commercial products (described as "tissue-engineered skin bioconstructs" by Shevchenko et al. [56]) available for skin repair and regeneration. Many of these products comprise a dermal-like layer and keratinocyte sheet. However, as the strategy most often 
adopted is the use of these in 3-D constructs (to replace lost dermis and epidermis) and not in a sheet, they fall outside of the scope of this review.

Fibrin sealant has been used as a support material to deliver sub-confluent cell layers of autologous keratinocytes to treat chronic leg ulcers $[57,58]$.

Human amnion (hAM) has been used clinically without cells for over a century for the treatment of open wounds and burns [59], and more recently in ophthalmological, gynaecological, urological and neurological surgery [60-62]. hAM has also been used for the cell culture/delivery of fibroblasts [63], corneal epithelial cells [64, 65], chondrocytes [66] and MSCs $[67,68]$. In the treatment of corneal limbal disease the current standard method is to culture the limbal cells on hAM and transplant the cells and the membrane into the eye [69].

\section{Limitations and Potential Problems}

\subsection{Disease Control and Variability}

Whilst animal (or donor human) biological materials are presumed to confer advantage from a biocompatibility point of view, these materials always carry the risk of disease transmission and in addition, often carry the risk of batch-to-batch variation [70]. There are also complex ethical/religious/cultural issues that mean that in some geographical territories animal/donor human approaches are not acceptable, and some of the techniques described above have complex logistical requirements which must be met. Disadvantages include:

1. The lengthy production of a cell sheet following the initial biopsy. A lead time of up to 4 weeks is required to prepare autologous cell sheets (although more typically 2-3 weeks) [39].

2. Timing of sheet production to the patient. The short shelf-life of the sheet means that patient needs to be ready to receive the graft (e.g. infection free with a suitable graft bed) when the sheet is ready.

3. Use of enzymes to remove the sheet from the cultureware and sheet fragility.

4. The current use of xenobiotic materials in sheet production. This routinely includes fibroblast feedlayers and serum [71].

5. The variability in the product, arising from use of a patient's own cells and a number of biological reagents that are susceptible to changing quality. 
6. Transportation. The cell sheet must move from the lab to the patient (This is mitigated by placing manufacture very close to the medical facility. However, this introduces the issue of a laboratory that can only service a small footprint and costs become very high.)

7. Cell sheet manufacture is manual and requires a highly skilled operator to produce the sheets and surgeons who are familiar with the technology and handling of sheets.

Modern CEA technologies are still based upon the R\&G method for cell sheet production and delivery to patients. However, as described above the original $R \& G$ procedure $[37,72]$ is timeconsuming, multistep and labour intensive. In 2006, the Sheffield burns group (Hernon et al) reported on a 10-year audit using CEAs for patients with extensive burns [73]. They found that the clinical take using CEAs averaged only $45 \%$ (as had been reported by other groups) but of equal concern was that over half of all cells cultured for these patients had to be discarded owing to difficulties of timing the production of CEA sheets to the needs of the patients. One of the problems identified was that CEAs could not be used until they had reached confluence i.e. an integrated sheet. This took on average 12 days. Further once an integrated sheet was formed it needed to be used within 2-3 days, or the cells lost the ability to attach to wound beds.

For cell therapies to become more effective and convenient, while at lower cost, there is a need for techniques which facilitate delivery of expanded cells directly to the patient. Ideally this would include seeding and expansion of the cells on the delivery substrate.

\subsection{Manufacture, Storage and Transport}

Storage and transportation of cell therapy products is easily overlooked during early R\&D but these are aspects of cell sheet production which should be addressed at an early stage to ensure cost effective scale up and commercialization. Cell preservation, distribution, and handling costs have been identified by the Cell Manufacturing Consortium as one of the six areas of focus critical to commercialisation. With cost as a key hurdle, centralised cell expansion/culture facilities are currently the most viable. While having fewer processing plants does minimise specific costs, and potentially increase the consistency of the cell product, this also invariably leads to trade-offs: The cell product will need to be stored and transported to the patient and in the context of "release criteria" the quality/integrity of the product assured. Most cell therapy clinical trials utilise cell suspensions with multiple administration vectors (IV infusion, administration within a hydrogel carrier etc.). Cell suspensions have well-defined cryopreservation methods leading to a straightforward process of thawing and administering 
the cell therapy. In contrast, there are few defined and effective protocols and methods for the cryopreservation and subsequent administration of cell sheets. For this reason, cell sheet therapies are either limited to short distances from the culture facility or complex thermally controlled transportation vehicles are used [74]. The quality of a cell product depends on precise conditions during transportation and we can expect in the future to see far more integrated payload monitoring systems.

With the growth of the cell therapy field, we can expect the regulatory scrutiny over the safety, consistency and efficacy of biological products to become increasingly stringent over time. Decisions made now should endeavour to future-proof processes which may be adopted for the long-term.

\section{Modern development of synthetic substrates}

Given the challenges described above, and further additional challenges presented in the storage, transport and clinical delivery of cell sheets, there has been significant research and commercial focus on the use of synthetic materials for cell sheets. This section considers the use of a range of material strategies in the manufacture through to clinical delivery of cell sheets.

Poly(lactic acid) (PLA) and poly(glycolic acid) (PGA) as well as copolymers thereof (PLGA) are among the most well researched synthetic biodegradable polymers; they have shown great promise within the field of tissue engineering for cell and drug delivery applications [75-84]. Other synthetic biodegradable and non-biodegradable polymers that are therapeutically approved by the FDA have been well documented [85, 86].[85, 86]

Despite the considerable time and money put into the development of advanced new polymers for use in medicine, the synthetic materials used in cell delivery have been selected not because they are the best in terms of bio-performance e.g. cellular attachment/release, but because they are readily sourced, well characterised, available in medical grade purities and, most importantly, are already approved for use by the FDA/EMA. They are generally selected based upon bulk characteristics, such as biodegradability/conformability that make them favourable for use in vivo and cell-material limitations are overcome with the use of adhesive proteins [87, 88] or chemical surface modifications [89]. Consequently, protocols often describe the coating of synthetic materials with animal-derived products, such as rat tail collagen, to improve cell attachment [90]. Laserskin (TissueTech), as an example, comprises autologous keratinocytes 
and fibroblasts grown upon a microperforated hyaluronic acid membrane [24]. According to the available publications, this system facilitated the effective treatment of diabetic foot ulcers as shown in randomized clinical trials where a $70.3 \%$ rate of wound closure was achieved [24].

For cell sheets to become a commercial reality, there is a strong commercial imperative to reduce complexity of manufacture, reduce cost of goods (COGs), and increase efficiency and efficacy. There are also significant logistic and supply chain issues to be solved. The use of smart bespoke surfaces in CT manufacture, logistics and patient delivery offers opportunities to meet these challenges without introduction of new costs.

Advantages of using bespoke synthetic surfaces for cell sheet manufacture include:

i. Better quality control - significant and often unknown variation in the surfaces of materials often significantly impact on safety, efficacy and consistency of the product.

ii. The potential for cell expansion (although this may not be ideal), long term storage (cryo) and transportation on this surface

iii. In the clinic, improved delivery efficiency - leading to reduced cell dose requirement and consequently lower COG's.

iv. Simplicity - Vertical integration into manufacturing process means that carrier sheets can be the expansion surface, storage, transportation and delivery device.

v. Better clinical impact - By increasing the manufacturing footprint and reducing COGs, cell therapy approaches will reach a wider market.

The application of thin polymeric coatings would allow the use of FDA approved substrates as the bulk material. Selection of the appropriate chemical functionality to enable appropriate cell attachment, expansion or delivery remains a challenge. Recently, a group at Nottingham University developed a high-throughput analysis technique which enables the identification of polymer coatings that promote stem cell attachment and maintenance of pluripotency [91]. Using this technique, more than 100 polymers can be tested in parallel and promising polymers can then be tested as co-polymers very quickly to identify ideal substrate coatings. This selection method has also been applied to anti-bacterial coatings [92].

Once a desirable polymeric surface has been identified, specific technologies can be used to 
engineer bespoke surfaces. These technologies include bulk polymerization, surface grafting [93], surface initiated polymerization techniques such as RAFT and ATRP [94] self-assembled monolayers.

\section{Currently available techniques}

Whilst enzymatic detachment of the CEA cell sheet is effective, it is likely that the use of proteolytic enzymes, such as dispase, can lead to damage of critical cell surface proteins such as ion channels, growth factor receptors and cell-to-cell junction proteins. It stands to reason that a complete cell sheet with extracellular matrix fully intact provides a better environment for cells to function that an enzymatically treated suspension. With this ambition, Teruo Okano first described a versatile method for obtaining cell sheets without the use of enzymatic detachment in 1990 [95]. This method employed the thermoresponsive polymer poly ( $\mathrm{N}$ isopropylacrylamide) (NIPAM) which undergoes a phase change resulting in a change in the wettability of the surface. The cell sheet can be released by changing the temperature of the culture substrate. The implications of this technology were quickly understood and a range of tissue cultureware employing this surface treatment is available from CellSeed under the brand UpCell. Cell sheets formed using this culture surface have been explored for a multitude of applications including delivery of keratinocytes [96], retinal pigment epithelial cells [97], corneal epithelial cells [98], oral mucosal epithelial cells [10, 99], urothelial cells [100, 101], periodontal ligament cells [102, 103], aortic endothelial cells [104, 105], corneal endothelial cells $[100,101][102,103][104,105][106,107]$, cardiac myocytes [108, 109], and kidney epithelial cells [110].[110]

Corneal transplantation is the current gold-standard treatment for corneal epithelial dysfunction caused by disease or trauma. Whilst effective, there is still a substantial risk of rejection and a shortage of donor corneas. Tissue engineering approaches are gathering a great deal of momentum and enzymatic release of cultured corneal epithelial cells requires a carrier to deliver the cell sheet. Common scaffold carriers such as PLA are often thought to be unsuitable for corneal regeneration due to acidic degradation products so typical carriers are amniotic membrane [111] or fibrin gel [112]. While these work, they do require the use of additional biological materials increasing complexity and disease risks. Cell sheets cultured and released using NIPAM thermoresponsive cultureware are more robust that those released with dispase 
enzymatic treatment so additional carriers are not required. These cell sheets can be placed directly onto the host cornea and adhere without the need for sutures [98]. The exclusion of carrier substrates maximizes corneal transparency. Additionally, direct interaction between the transplanted epithelial sheet and host stroma populated by keratocytes, likely allows for environmental cues that may be necessary for the maintenance of a healthy ocular surface [113].

The potential for layering these cell sheets to generate complex 3D architectures has not gone unnoticed. Cell sheets harvested using non-enzymatic release methods and constructs fabricated by layering can offer a cell therapy solution with characteristics between that of cell suspensions and cells on scaffolds. The layering of cardiomyocyte cell sheets has produced tissues like cardiac muscle. By utilizing non-enzymatic release methods, cell surface proteins such as connexins, necessary for the synchronous beatings seen in native tissues, can be maintained [113].

Plasma polymerization for engineering bespoke surfaces is a very promising surface technology already supporting FDA and EMA approved therapies and devices [114]. Plasma treatment using inert or atmospheric gases for treating tissue culture substrates is well established [115].[115] This technique has been widely adopted for increasing surface wettability and cell adherence, although there are limitations with this technology that include surface stability. This low cost, versatile and highly reproducible coating technology affords provision of coatings of precise chemistry, thickness and physical properties and is readily integrated into manufacturing processes [116]. In this context, it has a >20 year track record and wide industry acceptance that other (newer) technologies have yet to achieve. Plasma polymerization is a method whereby a plasma source generates a gas discharge providing the energy to fragment a liquid/gas precursor. These reactive precursor fragments then initiate polymerization. These polymers adhere to a wide range of substrates and are able to coat complex geometries $[117,118]$. Through a careful selection of precursors, specific surface chemical functionality can be attained including carboxylic acids [119], amines [120], ethers [121, 122], alcohols [123], siloxanes [124] and halogenated hydrocarbons [119]. As plasma polymerization is substrate independent, this gives researchers the ability to deliver cell sheets directly from culture surfaces to the site of interest and from a wide range of base materials and formats. Another advantage of plasma polymerization is that it enables coating of surfaces with precursors which are usually non-reactive; the energy for deposition is provided by the 
electrical power supplied to the plasma phase. This may seem trivial but it unlocks a new set of approaches.

The development of plasma polymerized surfaces for carrying cells in CT, started from a pilot project aimed at refining keratinocyte culture by defining a synthetic plasma deposited [125] surface which could maintain keratinocytes in a proliferative phenotype in which they would be capable of attaching, migrating and forming colonies [126, 127]. This work established that acid functionalised surfaces readily supported attachment and colony formation [128, 129], but also, were capable of supporting cell delivery to an artificial wound bed and at a level comparable to collagen.

Following these in vitro trials, two human trials were performed using patients with neuropathic diabetic foot ulcers $[130,131]$. These trials demonstrated the utility of this method of cell delivery in healing wounds which had not responded to conventional therapies. Of the 30 wounds treated across these two trials, 24 healed and statistically it was shown this could be attributed to the delivery of the cultured cells, not the dressing. This technology was commercialised and became known as $\mathrm{MySkin}^{\mathrm{TM}}$, which was subsequently trialled with other indications including burns and showed similar success [132].

A series of studies and a follow up review [30] highlight the advantages of using an engineered carrier surface $\left(\mathrm{MySkin}^{\mathrm{TM}}\right)$ vs CEA in the treatment of burns and non-healing wounds [129, 130, 132-134]. Whilst the simplicity of the MySkin ${ }^{\mathrm{TM}}$ carrier was highlighted, the major advantage identified was the ability to time cell delivery to the patient to the needs of the patient.

\section{Future directions}

\subsection{Allogenic delivery - Stem Cells}

The stellar rise of mesenchymal stem cells (MSCs) as a potential treatment for a range of diseases including osteoarthritis [135], chronic obstructive pulmonary disease [136], stroke [137] and autoimmune diseases [138] has led a number of groups to explore their potential in the healing of chronic wounds [139].

These cells have the potential to be manufactured in their billions and this feature further reduces the overall COG. In the use of MSCs in wound healing one potential problem identified 
is the injection of these cells near or into wounds, which may be difficult to do from the clinician's perspective and undesirable from the patients.

Consequently, two separate studies have looked at the delivery of MSCs from plasma polymerised dressings.

The success of the MySkin ${ }^{\mathrm{TM}}$ product led the MacNeil team (University of Sheffield) to employ the same coating to see if it could be used to deliver bone marrow derived MSC's [140]. From a therapeutic point of view there was no evidence that the MSC's had started to differentiate on the coating. The cells were delivered successfully to the DED wound bed model and when delivered to endothelial colony forming cells showed that they were still functional as they supported tubule formation. This validated the hypothesis that the coating could be used to deliver MSC's to wounds [140].

The second focussed on the delivery of human adipose tissue derived MSCs (AT-MSCs) to murine full-thickness excisional wounds from plasma polymerized coatings [141]. It was first established that after four days culture on these coatings the AT-MSCs maintained their full range of cell surface markers, their capacity for colony forming, their ability to differentiate, and capacity for immunosuppression. In murine wounds, bandage delivery was compared to intradermal injection of AT-MSCs. Both modes of delivery significantly enhanced wound healing when compared to the control of an empty carrier. There was good transfer from the plasma polymerized acrylic acid dressing to the wounds (>80\%). Furthermore, the authors reported that carrier-delivered AT-MSCs led to down regulation of the inflammation marker (TNF-alpha), upregulation of anti-inflammatory M2 macrophages and induced angiogenesis, myoblast differentiation and granulation tissue formation.

More recently, amine functionalised plasma polymer coatings have been used to deliver multipotent adult progenitor cells to acute wounds in mice [142]. It was shown that the surface density of amine functional groups is critical for cells to adhere and survive on the dressing, but also to spontaneously leave the dressing when placed in contact with the wound. The combination of these studies show that plasma polymerised surfaces can be adapted to deliver different cell types to a range of different clinical indications. Critically, it seems the combination of cell type and surface chemistry (functional group type and density) are key to maintaining the phenotype and function of the cells, and delivering them to wounds. 


\subsection{Cryo-preservation}

Cryo-preservation (typically at either $-80^{\circ} \mathrm{C}$ or $-196^{\circ} \mathrm{C}$ ) offers the opportunity of much longer shelf-lives, depending upon temperature of months to years. However, cryo-preservation of cells requires further cell manipulation with the use a cryo-protectant. There is no shortage of cold-chain logistics companies, but if this is the chosen method for storage and distribution even at the earliest stages of development, the cell product needs to be optimised for storage and transit. For example, a $1 \mathrm{ml}$ cell product will be far more susceptible to an adverse temperature event that a $200 \mathrm{ml}$ cell product. These kinds of factors need to be considered at the outset.

The major limiting factor of all tissue engineered products to date has been cost. Particularly, in the production of autologous products, the process is labour intensive. It is therefore imperative that the materials aspects of a product are addressed to minimise costs and avoid over-engineering. The MySkin ${ }^{\mathrm{TM}}$ product partially addressed these concerns by having: (i) an inexpensive raw material base, (ii) readily scalable materials production, (iii) use of only a single cell type, and (iv) limited use of expensive animal-derived products.

However, to further address these concerns a "cryo" variant was developed that comprised a medical grade polymer that was plasma polymerized and seeded with donor keratinocytes (neonatal foreskin) and freeze dried (a cryopreservative was used). This product had a shelf life of 6 months to 3 years depending upon storage temperature and was transported to the clinic in an isothermal box, where it rapidly thawed on removal, prior to application. Whilst partially addressing cost and logistics issues, the preparation of this product was still labour intensive - with cell culture being the major cost component.

Dermagraft [143] provides a good model for cell storage/transportation and patient delivery. While not a true cell sheet product, Dermagraft is a thin 3D scaffold seeded with fibroblasts. This product is supplied in a frozen form $\left(-70^{\circ} \mathrm{C}\right)$, which rapidly thaws in the clinic. The combination of a 3D polyglactin mesh and an extensive extracellular matrix benefits the cryopreservation of the attached fibroblasts. This model was adapted for cryo-skin cell sheet product, CryoSkin ${ }^{\mathrm{TM}}$.

\subsection{Serum-free delivery}


There is a huge push towards xenobiotic free cell culture from regulatory bodies. With many new formulations being marketed (HEScGRO, Millipore; mTeSR1, STEMCELL Technologies; TeSR2, STEMCELL Technologies; StemPro, Invitrogen; NutriStem, STEMGENT; E8TM, GIBCO; XVIVO 10, Lonza; RegES; hESF9). One way to achieve reduction or removal of xenobiotic, and indeed very expensive components in cell culture (e.g. growth factors) is by using novel materials [144].

There is a considerable and increasingly focus on surface binding the required motifs for cell attachment, signalling (for example mitogens). The advantage of this approach is less waste (vs. adding to cell culture medium), location of motifs where they are needed and in the case of potentially hazardous motifs, their ready removal at the end of the process on the supporting material This is a key area we see for development of materials for cell sheet delivery.

\section{Conclusions}

There has been a paradigm shift in recent years for methods used to deliver cell therapies. Delivering cells without the use of enzymatic treatments, in a simple to use format with wellunderstood clinical outcomes has been the driving force for research in this field. As an alternative to injections of cell suspensions, the use of planar surfaces has enabled simple and effective delivery of cells to different clinical indications [99, 108, 145, 146], demonstrating the versatility of this approach. The role of materials science in designing bespoke chemically functionalised surfaces has been crucial in progressing many of these applications. The true scope and importance of surfaces in cell therapy is still to be fully revealed. Continued research is essential to develop the technology, validate outcomes, and drive down cost of goods. The future of this field involves fully elucidating why certain functional groups affect cell-surface interactions and importantly, what are the downstream effects on the cell product? With recent leaps in proteomics, this is a growth area with an exciting future. Translation from bench to bedside requires navigating issues of scale-up and commercial viability. It is imperative that biologists, clinicians and materials scientists continue to work together to solve these issues to realise clinical outcomes.

\section{Acknowledgements}

The authors would also like to acknowledge the support of the Cooperative Research Centre for Cell Therapy Manufacturing and the Australian Government's Cooperative Research Centres Program. 
[1] R. Lower, An account of the experiment of transfusion, practiced upon a man in London. 1667, The Yale journal of biology and medicine 75(5-6) (2002) 293.

[2] D. Schultheiss, J. Denil, U. Jonas, Rejuvenation in the early 20th century, Andrologia 29(6) (1997) 351-355.

[3] T.E. Starzl, History of clinical transplantation, World journal of surgery 24(7) (2000) 759782.

[4] F.H. Gage, Cell therapy, Nature 392(6679) (1998) 18.

[5] V.F. Segers, R.T. Lee, Biomaterials to enhance stem cell function in the heart, Circulation research 109(8) (2011) 910-922.

[6] D. Ratner, SKIN GRAFTING: From Here to There, Dermatol Clin 16(1) (1998) 75-90.

[7] D.C. Adams, M.L. Ramsey, Grafts in dermatologic surgery: review and update on full-and split-thickness skin grafts, free cartilage grafts, and composite grafts, Dermatologic surgery 31(s2) (2005) 1055-1067.

[8] J.R. Wolfe, A new method of performing plastic operations, British medical journal 2(768) (1875) 360.

[9] H. Green, O. Kehinde, J. Thomas, Growth of cultured human epidermal cells into multiple epithelia suitable for grafting, Proceedings of the National Academy of Sciences 76(11) (1979) 5665-5668.

[10] Y. Hayashida, K. Nishida, M. Yamato, K. Watanabe, N. Maeda, H. Watanabe, et al, Ocular surface reconstruction using autologous rabbit oral mucosal epithelial sheets fabricated ex vivo on a temperature-responsive culture surface, Investigative ophthalmology \& visual science 46(5) (2005) 1632-1639.

[11] A. Ito, M. Hayashida, H. Honda, K.-I. Hata, H. Kagami, M. Ueda, et al, Construction and harvest of multilayered keratinocyte sheets using magnetite nanoparticles and magnetic force, Tissue engineering 10(5-6) (2004) 873-880.

[12] O. Guillaume-Gentil, Y. Akiyama, M. Schuler, C. Tang, M. Textor, M. Yamato, et al, Polyelectrolyte coatings with a potential for electronic control and cell sheet engineering, Advanced Materials 20(3) (2008) 560-565.

[13] O. Guillaume-Gentil, O.V. Semenov, A.H. Zisch, R. Zimmermann, J. Vörös, M. Ehrbar, $\mathrm{pH}$-controlled recovery of placenta-derived mesenchymal stem cell sheets, Biomaterials 32(19) (2011) 4376-4384.

[14] T. Owaki, T. Shimizu, M. Yamato, T. Okano, Cell sheet engineering for regenerative medicine: current challenges and strategies, Biotechnology journal 9(7) (2014) 904-914.

[15] D.B. Haddow, S. MacNeil, R.D. Short, A cell therapy for chronic wounds based upon a plasma polymer delivery surface, Plasma Processes and Polymers 3(6-7) (2006) 419-430.

[16] P. Deshpande, M. Notara, N. Bullett, J.T. Daniels, D.B. Haddow, S. MacNeil, Development of a surface-modified contact lens for the transfer of cultured limbal epithelial cells to the cornea for ocular surface diseases, Tissue Engineering Part A 15(10) (2009) 28892902.

[17] T. Ohki, M. Yamato, D. Murakami, R. Takagi, J. Yang, H. Namiki, et al, Treatment of oesophageal ulcerations using endoscopic transplantation of tissue-engineered autologous oral mucosal epithelial cell sheets in a canine model, Gut 55(12) (2006) 1704-1710.

[18] C.-S. Lin, Stem Cell Therapy for the Bladder: Where Do We Stand?, The Journal of urology 185(3) (2011) 779-780.

[19] R.E. MacLaren, R.A. Pearson, Stem cell therapy and the retina, Eye 21(10) (2007) 13521359. 
[20] Í. Ortega, A.J. Ryan, P. Deshpande, S. MacNeil, F. Claeyssens, Combined microfabrication and electrospinning to produce 3-D architectures for corneal repair, Acta Biomaterialia 9(3) (2013) 5511-5520.

[21] M. Kanzaki, M. Yamato, H. Hatakeyama, C. Kohno, J. Yang, T. Umemoto, et al, Tissue engineered epithelial cell sheets for the creation of a bioartificial trachea, Tissue engineering 12(5) (2006) 1275-1283.

[22] L.I. Mambelli, G.H. Winter, A. Kerkis, E. Malschitzky, R.C. Mattos, I. Kerkis, A novel strategy of mesenchymal stem cells delivery in the uterus of mares with endometrosis, Theriogenology 79(5) (2013) 744-50.

[23] G. Zhang, X. Wang, Z. Wang, J. Zhang, L. Suggs, A PEGylated Fibrin Patch for Mesenchymal Stem Cell Delivery, Tissue Engineering 12(1) (2006) 9-19.

[24] H. Beele, M. De La Brassine, J. Lambert, E. Suys, C. De Cuyper, J. Decroix, et al, A prospective multicenter study of the efficacy and tolerability of cryopreserved allogenic human keratinocytes to treat venous leg ulcers, The international journal of lower extremity wounds 4(4) (2005) 225-233.

[25] R.E. Horch, H. Bannasch, J. Kopp, C. Andree, G.B. Stark, Single-cell suspensions of cultured human keratinocytes in fibrin-glue reconstitute the epidermis, Cell transplantation 7(3) (1998) 309-317.

[26] S.T. Boyce, R.J. Kagan, N.A. Meyer, K.P. Yakuboff, G.D. Warden, Cultured skin substitutes combined with integra artificial skin to replace native skin autograft and allograft for the closure of excised full- thickness burns, Journal of Burn Care and Rehabilitation 20(6) (1999) 453-461.

[27] F.A. Navarro, M.L. Stoner, C.S. Park, J.C. Huertas, H.B. Lee, F.M. Wood, et al, Sprayed keratinocyte suspensions accelerate epidermal coverage in a porcine microwound model, Journal of Burn Care and Rehabilitation 21(6) (2000) 513-518.

[28] A.G. Bettman, Homogenous Thiersch grafting as a life saving measure, The American Journal of Surgery 39(1) (1938) 156-162.

[29] H.P. Giele, M.L. Stoner, F.M. Wood, An alternative technique for the harvesting of cultured epithelial cell sheets, Methods in Cell Science 17(4) (1995) 233-236.

[30] C.A. Hernon, R.A. Dawson, E. Freedlander, R. Short, D.B. Haddow, M. Brotherston, et al, Clinical experience using cultured epithelial autografts leads to an alternative methodology for transferring skin cells from the laboratory to the patient, Regenerative medicine 1(6) (2006) 809-821.

[31] L. Martínez-Santamaría, S. Guerrero-Aspizua, M. Del Río, Skin bioengineering: Preclinical and clinical applications, Bioingeniería cutánea: aplicaciones preclínicas y clínicas 103(1) (2012) 5-11.

[32] L.G. Ovington, Advances in wound dressings, Clinics in Dermatology 25 (2007) 33-38.

[33] J.G. Rheinwald, Chapter 15 Serial Cultivation of Normal Human Epidermal Keratinocytes, 1980, pp. 229-254.

[34] F. Wood, K. Liddiard, A. Skinner, J. Ballentyne, Scar management of cultured epithelial autograft, Burns 22(6) (1996) 451-454.

[35] F.M. Wood, M.L. Kolybaba, P. Allen, The use of cultured epithelial autograft in the treatment of major burn injuries: A critical review of the literature, Burns 32(4) (2006) 395401.

[36] J.G. Rheinwald, H. Green, Serial cultivation of strains of human epidermal keratinocytes: the formation of keratinizing colonies from single cells, Cell 6(3) (1975) 331-334.

[37] N. O'Connor, J. Mulliken, S. Banks-Schlegel, O. Kehinde, H. Green, Grafting of burns with cultured epithelium prepared from autologous epidermal cells, The Lancet 317(8211) (1981) 75-78. 
[38] G.r. Gallico, N.E. O'Connor, C.C. Compton, O. Kehinde, H. Green, Permanent coverage of large burn wounds with autologous cultured human epithelium, New England Journal of Medicine (311) (1984) 448-51.

[39] B.S. Atiyeh, M. Costagliola, Cultured epithelial autograft (CEA) in burn treatment: three decades later, Burns 33(4) (2007) 405-413.

[40] D. Kym, H. Yim, J. Yoon, H.T. Yang, Y.S. Cho, J. Hur, et al, The application of cultured epithelial autografts improves survival in burns, Wound Repair and Regeneration (2015).

[41] H.-S. Kim, X. Jun Song, C.S. de Paiva, Z. Chen, S.C. Pflugfelder, D.-Q. Li, Phenotypic characterization of human corneal epithelial cells expanded ex vivo from limbal explant and single cell cultures, Experimental eye research 79(1) (2004) 41-49.

[42] N. Koizumi, L.J. Cooper, N.J. Fullwood, T. Nakamura, K. Inoki, M. Tsuzuki, et al, An evaluation of cultivated corneal limbal epithelial cells, using cell-suspension culture, Investigative ophthalmology \& visual science 43(7) (2002) 2114-2121.

[43] M. Griffith, R. Osborne, R. Munger, X. Xiong, C.J. Doillon, N.L. Laycock, et al, Functional human corneal equivalents constructed from cell lines, Science 286(5447) (1999) 2169-2172.

[44] K. Chakrabarty, R. Dawson, P. Harris, C. Layton, M. Babu, L. Gould, et al, Development of autologous human dermal-epidermal composites based on sterilized human allodermis for clinical use, British Journal of Dermatology 141(5) (1999) 811-823.

[45] K.H. Chakrabarty, R.A. Dawson, P. Harris, C. Layton, M. Babu, L. Gould, et al, Development of autologous human dermal-epidermal composites based on sterilized human allodermis for clinical use, Br. J. Dermatol. 141(5) (1999) 811-823.

[46] M.M. Ghosh, S. Boyce, C. Layton, E. Freedlander, S. MacNeil, A Comparison of the Methodologies for the Preparation of Human Epidermal-Dermal Composites, Ann Plast Surg 39(4) (1997) 390-404.

[47] Q. Huang, R.A. Dawson, D.E. Pegg, J.N. Kearney, S. MacNeil, Use of peracetic acid to sterilize human donor skin for production of acellular dermal matrices for clinical use, Wound Repair Regen 12(3) (2004) 276-287.

[48] S. MacNeil, Progress and opportunities for tissue-engineered skin, Nature 445 (2007) 874880.

[49] S. MacNeil, J. Shepherd, L. Smith, Production of Tissue-Engineered Skin and Oral Mucosa for Clinical and Experimental Use, in: J.W. Haycock (Ed.), 3D Cell Culture, Humana Press2011, pp. 129-153.

[50] K. Moharamzadeh, L.E. Smith, K. Franklin, A.J. Ryan, C. Freeman, M.H. Thornhill, et al, Transplantation of oral mucosa explants using different biological and synthetic membranes in an attempt to achieve one-stage reconstruction of soft-tissue defects, Oral Surgery 5(3) (2012) 118-126.

[51] S. Bhargava, C.R. Chapple, A.J. Bullock, C. Layton, S. Macneil, Tissue-engineered buccal mucosa for substitution urethroplasty, BJU Int. 93(6) (2004) 807-811.

[52] S. Bhargava, J.M. Patterson, R.D. Inman, S. MacNeil, C.R. Chapple, Tissue-engineered buccal mucosa urethroplasty-clinical outcomes, European urology 53(6) (2008) 1263-9.

[53] P.S. Sahota, J.L. Burn, M. Heaton, E. Freedlander, S.K. Suvarna, N.J. Brown, et al, Development of a reconstructed human skin model for angiogenesis, Wound repair and regeneration 11(4) (2003) 275-284.

[54] A.D. Metcalfe, M.W.J. Ferguson, Tissue engineering of replacement skin: The crossroads of biomaterials, wound healing, embryonic development, stem cells and regeneration, Journal of the Royal Society Interface 4(14) (2007) 413-417.

[55] C. Pereira, W. Gold, D. Herndon, Review paper: Burn coverage technologies: Current concepts and future directions, Journal of Biomaterials Applications 22(2) (2007) 101-121. 
[56] R.V. Shevchenko, S.L. James, S.E. James, A review of tissue-engineered skin bioconstructs available for skin reconstruction, Journal of The Royal Society Interface 7(43) (2010) 229-258.

[57] S. Johnsen, T. Ermuth, E. Tanczos, H. Bannasch, R. Horch, I. Zschocke, et al, Treatment of therapy-refractive ulcera cruris of various origins with autologous keratinocytes in fibrin sealant, Vasa 34(1) (2005) 25-29.

[58] W. Vanscheidt, A. Ukat, V. Horak, H. Brüning, J. Hunyadi, R. Pavlicek, et al, Treatment of recalcitrant venous leg ulcers with autologous keratinocytes in fibrin sealant: a multinational randomized controlled clinical trial, Wound repair and regeneration 15(3) (2007) 308-315.

[59] H.S. Dua, Amniotic membrane transplantation, British journal of ophthalmology 83(6) (1999) 748-752.

[60] M. Subrahmanyam, Amniotic membrane as a cover for microskin grafts, Br J Plast Surg 48(7) (1995) 477-478.

[61] D. Ward, J. Bennett, H. Burgos, J. Fabre, The healing of chronic venous leg ulcers with prepared human amnion, Br J Plast Surg 42(4) (1989) 463-467.

[62] W.C. Quinby Jr, H.C. Hoover, M. Scheflan, P.T. Walters, S.A. Slavin, C.C. Bondoc, Clinical trials of amniotic membranes in burn wound care, Plast Reconstr Surg 70(6) (1982) 711-716.

[63] S.-P. Wilshaw, J. Kearney, J. Fisher, E. Ingham, Biocompatibility and potential of acellular human amniotic membrane to support the attachment and proliferation of allogeneic cells, Tissue Engineering Part A 14(4) (2008) 463-472.

[64] P. Wan, X. Wang, P. Ma, N. Gao, J. Ge, Y. Mou, et al, Cell delivery with fixed amniotic membrane reconstructs corneal epithelium in rabbits with limbal stem cell deficiency, Investigative ophthalmology \& visual science 52(2) (2011) 724-730.

[65] T. Nakamura, M. Yoshitani, H. Rigby, N.J. Fullwood, W. Ito, T. Inatomi, et al, Sterilized, freeze-dried amniotic membrane: a useful substrate for ocular surface reconstruction, Investigative ophthalmology \& visual science 45(1) (2004) 93-99.

[66] C.Z. Jin, S.R. Park, B.H. Choi, K.-Y. Lee, C.K. Kang, B.-H. Min, Human amniotic membrane as a delivery matrix for articular cartilage repair, Tissue engineering 13(4) (2007) 693-702.

[67] S.-L. Tan, S. Sulaiman, B. Pingguan-Murphy, L. Selvaratnam, C.-C. Tai, T. Kamarul, Human amnion as a novel cell delivery vehicle for chondrogenic mesenchymal stem cells, Cell and tissue banking 12(1) (2011) 59-70.

[68] S.S. Kim, C.K. Song, S.K. Shon, K.Y. Lee, C.H. Kim, M.J. Lee, et al, Effects of human amniotic membrane grafts combined with marrow mesenchymal stem cells on healing of fullthickness skin defects in rabbits, Cell and Tissue Research (2009) 1-8.

[69] R.J.-F. Tsai, S.C. Tseng, Human allograft limbal transplantation for corneal surface reconstruction, Cornea 13(5) (1994) 389-400.

[70] I.R. Schwab, N.T. Johnson, D.G. Harkin, Inherent risks associated with manufacture of bioengineered ocular surface tissue, Archives of ophthalmology 124(12) (2006) 1734-1740.

[71] A. Meana, J. Iglesias, M. Del Rio, F. Larcher, B. Madrigal, M. Fresno, et al, Large surface of cultured human epithelium obtained on a dermal matrix based on live fibroblast-containing fibrin gels, Burns 24(7) (1998) 621-630.

[72] J.G. Rheinwatd, H. Green, Serial cultivation of strains of human epidemal keratinocytes: the formation keratinizin colonies from single cells, Cell 6(3) (1975) 331-343.

[73] C.A. Hernon, R.A. Dawson, E. Freedlander, R. Short, D.B. Haddow, M. Brotherston, et al, Clinical experience using cultured epithelial autografts leads to an alternative methodology for transferring skin cells from the laboratory to the patient, Regen Med 1(6) (2006) 809-821. 
[74] T. Nozaki, M. Yamato, T. Inuma, K. Nishida, T. Okano, Transportation of transplantable cell sheets fabricated with temperature-responsive culture surfaces for regenerative medicine, Journal of tissue engineering and regenerative medicine 2(4) (2008) 190-195.

[75] S.L. Ishaug-Riley, L.E. Okun, G. Prado, M.A. Applegate, A. Ratcliffe, Human articular chondrocyte adhesion and proliferation on synthetic biodegradable polymer films, Biomaterials 20(23-24) (1999) 2245-2256.

[76] C.E. Holy, C. Cheng, J.E. Davies, M.S. Shoichet, Optimizing the sterilization of PLGA scaffolds for use in tissue engineering, Biomaterials 22(1) (2000) 25-31.

[77] K.W. Ng, H.L. Khor, D.W. Hutmacher, In vitro characterization of natural and synthetic dermal matrices cultured with human dermal fibroblasts., Biomaterials 25 (2004) 2807-2818.

[78] K.W. Ng, D.W. Hutmacher, Reduced contraction of skin equivalent engineered using cell sheets cultured in 3D matrices, Biomaterials 27(26) (2006) 4591-4598.

[79] K.A. Blackwood, R. McKean, I. Canton, C.O. Freeman, K.L. Franklin, D. Cole, et al, Development of biodegradable electrospun scaffolds for dermal replacement, Biomaterials 29(21) (2008) 3091-3104.

[80] M. Biondi, F. Ungaro, F. Quaglia, P.A. Netti, Controlled drug delivery in tissue engineering, Adv Drug Deliv Rev 60(2) (2008) 229-242.

[81] S. Panseri, C. Cunha, J. Lowery, U. Del Carro, F. Taraballi, S. Amadio, et al, Electrospun micro- and nanofiber tubes for functional nervous regeneration in sciatic nerve transections, BMC Biotechnology 8 (2008).

[82] M. Selim, A.J. Bullock, K.A. Blackwood, C.R. Chapple, S. MacNeil, Developing biodegradable scaffolds for tissue engineering of the urethra, BJU Int 107(2) (2011) 296-302.

[83] C.D. Easton, A.J. Bullock, G. Gigliobianco, S.L. McArthur, S. MacNeil, Application of layer-by-layer coatings to tissue scaffolds - development of an angiogenic biomaterial, Journal of Materials Chemistry B 2(34) (2014) 5558-5568.

[84] L.J. White, G.T.S. Kirby, H.C. Cox, R. Qodratnama, O. Qutachi, F.R.A.J. Rose, et al, Acelerating protein release from microparticles for regenerative medicine applications, Materials Science and Engineering C 33 (2013) 2578-2583.

[85] M. Martina, D.W. Hutmacher, Biodegradable polymers applied in tissue engineering research: a review, Polymer International 56(2) (2007) 145-157.

[86] E. Marin, M.I. Briceño, C. Caballero-George, Critical evaluation of biodegradable polymers used in nanodrugs, International Journal of Nanomedicine 8 (2013) 3071-3091.

[87] R. Vohra, G. Thompson, H. Sharma, H. Carr, M. Walker, Fibronectin coating of expanded polytetrafluoroethylene (ePTFE) grafts and its role in endothelial seeding, Artificial organs 14(1) (1990) 41-45.

[88] C. Pendegrass, M. El-Husseiny, G. Blunn, The development of fibronectin-functionalised hydroxyapatite coatings to improve dermal fibroblast attachment in vitro, Journal of Bone \& Joint Surgery, British Volume 94(4) (2012) 564-569.

[89] M.C. Serrano, M.T. Portolés, M. Vallet-Regí, I. Izquierdo, L. Galletti, J.V. Comas, et al, Vascular Endothelial and Smooth Muscle Cell Culture on NaOH-Treated Poly ( $\varepsilon$-caprolactone) Films: A Preliminary Study for Vascular Graft Development, Macromolecular bioscience 5(5) (2005) 415-423.

[90] P. De Corte, G. Verween, G. Verbeken, T. Rose, S. Jennes, A. De Coninck, et al, Feeder layer-and animal product-free culture of neonatal foreskin keratinocytes: improved performance, usability, quality and safety, Cell and tissue banking 13(1) (2012) 175-189.

[91] A. Celiz, J. Smith, A. Patel, R. Langer, D. Anderson, D. Barrett, et al, Chemically diverse polymer microarrays and high throughput surface characterisation: a method for discovery of materials for stem cell culture, Biomaterials Science (2014). 
[92] A.L. Hook, C.Y. Chang, J. Yang, S. Atkinson, R. Langer, D.G. Anderson, et al, Discovery of novel materials with broad resistance to bacterial attachment using combinatorial polymer microarrays, Advanced Materials 25(18) (2013) 2542-2547.

[93] M. Yamato, C. Konno, M. Utsumi, A. Kikuchi, T. Okano, Thermally responsive polymergrafted surfaces facilitate patterned cell seeding and co-culture, Biomaterials 23(2) (2002) 561567.

[94] S. Saboohi, B.R. Coad, A. Michelmore, R.D. Short, H.J. Griesser, Hyperthermal Intact Molecular Ions Play Key Role in Retention of ATRP Surface Initiation Capability of Plasma Polymer Films from Ethyl $\alpha$-Bromoisobutyrate, ACS Applied Materials \& Interfaces 8(25) (2016) 16493-16502.

[95] N. Yamada, T. Okano, H. Sakai, F. Karikusa, Y. Sawasaki, Y. Sakurai, Thermo-responsive polymeric surfaces; control of attachment and detachment of cultured cells, Die Makromolekulare Chemie, Rapid Communications 11(11) (1990) 571-576.

[96] M. Yamato, M. Utsumi, A. Kushida, C. Konno, A. Kikuchi, T. Okano, Thermo-responsive culture dishes allow the intact harvest of multilayered keratinocyte sheets without dispase by reducing temperature, Tissue engineering 7(4) (2001) 473-480.

[97] H.V. Recum, A. Kikuchi, M. Yamato, Y. Sakurai, T. Okano, S.W. Kim, Growth factor and matrix molecules preserve cell function on thermally responsive culture surfaces, Tissue engineering 5(3) (1999) 251-265.

[98] K. Nishida, M. Yamato, Y. Hayashida, K. Watanabe, N. Maeda, H. Watanabe, et al, Functional bioengineered corneal epithelial sheet grafts from corneal stem cells expanded ex vivo on a temperature-responsive cell culture surface, Transplantation 77(3) (2004) 379-385. [99] K. Nishida, M. Yamato, Y. Hayashida, K. Watanabe, K. Yamamoto, E. Adachi, et al, Corneal reconstruction with tissue-engineered cell sheets composed of autologous oral mucosal epithelium, New England Journal of Medicine 351(12) (2004) 1187-1196.

[100] Y. Shiroyanagi, M. Yamato, Y. Yamazaki, H. Toma, T. Okano, Transplantable urothelial cell sheets harvested noninvasively from temperature-responsive culture surfaces by reducing temperature, Tissue engineering 9(5) (2003) 1005-1012.

[101] Y. Shiroyanagi, M. Yamato, Y. Yamazaki, H. Toma, T. Okano, Urothelium regeneration using viable cultured urothelial cell sheets grafted on demucosalized gastric flaps, BJU international 93(7) (2004) 1069-1075.

[102] M. Hasegawa, M. Yamato, A. Kikuchi, T. Okano, I. Ishikawa, Human periodontal ligament cell sheets can regenerate periodontal ligament tissue in an athymic rat model, Tissue engineering 11(3-4) (2005) 469-478.

[103] T. Akizuki, S. Oda, M. Komaki, H. Tsuchioka, N. Kawakatsu, A. Kikuchi, et al, Application of periodontal ligament cell sheet for periodontal regeneration: a pilot study in beagle dogs, Journal of periodontal research 40(3) (2005) 245-251.

[104] A. Kushida, M. Yamato, C. Konno, A. Kikuchi, Y. Sakurai, T. Okano, Decrease in culture temperature releases monolayer endothelial cell sheets together with deposited fibronectin matrix from temperature-responsive culture surfaces, Journal of biomedical materials research 45(4) (1999) 355-362.

[105] M. Hirose, O.H. Kwon, M. Yamato, A. Kikuchi, T. Okano, Creation of designed shape cell sheets that are noninvasively harvested and moved onto another surface, Biomacromolecules 1(3) (2000) 377-381.

[106] T. Ide, K. Nishida, M. Yamato, T. Sumide, M. Utsumi, T. Nozaki, et al, Structural characterization of bioengineered human corneal endothelial cell sheets fabricated on temperature-responsive culture dishes, Biomaterials 27(4) (2006) 607-614.

[107] T. Sumide, K. Nishida, M. Yamato, T. Ide, Y. Hayashida, K. Watanabe, et al, Functional human corneal endothelial cell sheets harvested from temperature-responsive culture surfaces, The FASEB Journal 20(2) (2006) 392-394. 
[108] T. Shimizu, M. Yamato, Y. Isoi, T. Akutsu, T. Setomaru, K. Abe, et al, Fabrication of pulsatile cardiac tissue grafts using a novel 3-dimensional cell sheet manipulation technique and temperature-responsive cell culture surfaces, Circulation research 90(3) (2002) e40-e48. [109] T. Shimizu, H. Sekine, J. Yang, Y. Isoi, M. Yamato, A. Kikuchi, et al, Polysurgery of cell sheet grafts overcomes diffusion limits to produce thick, vascularized myocardial tissues, The FASEB journal 20(6) (2006) 708-710.

[110] A. Kushida, M. Yamato, Y. Isoi, A. Kikuchi, T. Okano, A noninvasive transfer system for polarized renal tubule epithelial cell sheets using temperature-responsive culture dishes, Eur Cell Mater 10 (2005) 23-30.

[111] R.J.-F. Tsai, L.-M. Li, J.-K. Chen, Reconstruction of damaged corneas by transplantation of autologous limbal epithelial cells, New England Journal of Medicine 343(2) (2000) 86-93.

[112] P. Rama, S. Bonini, A. Lambiase, O. Golisano, P. Paterna, M. De Luca, et al, Autologous fibrin-cultured limbal stem cells permanently restore the corneal surface of patients with total limbal stem cell deficiency1, Transplantation 72(9) (2001) 1478-1485.

[113] J. Yang, M. Yamato, C. Kohno, A. Nishimoto, H. Sekine, F. Fukai, et al, Cell sheet engineering: recreating tissues without biodegradable scaffolds, Biomaterials 26(33) (2005) 6415-6422.

[114] P.C. Nicolson, R.C. Baron, P. Chabrecek, A. Domschke, H.J. Griesser, A. Ho, et al, Extended wear ophthalmic lens, Google Patents, 1998.

[115] C.F. Amstein, P.A. Hartman, Adaptation of plastic surfaces for tissue culture by glow discharge, Journal of clinical microbiology 2(1) (1975) 46-54.

[116] H. Yasuda, Plasma polymerization, Academic press 2012.

[117] A. Kettle, A.J. Beck, L. O'toole, F. Jones, R. Short, Plasma polymerisation for molecular engineering of carbon-fibre surfaces for optimised composites, Composites science and technology 57(8) (1997) 1023-1032.

[118] H. Yasuda, Plasma polymerization, Academic press1985.

[119] S.J. Lamont-Friedrich, T.D. Michl, C. Giles, H.J. Griesser, B.R. Coad, Chlorine-rich plasma polymer coating for the prevention of attachment of pathogenic fungal cells onto materials surfaces, Journal of Physics D: Applied Physics 49(29) (2016) 294001.

[120] E. Makhneva, A. Manakhov, P. Skládal, L. Zajíčková, Development of effective QCM biosensors by cyclopropylamine plasma polymerization and antibody immobilization using cross-linking reactions, Surface and Coatings Technology 290 (2016) 116-123.

[121] A. Choukourov, I. Gordeev, O. Polonskyi, A. Artemenko, L. Hanyková, I. Krakovský, et al, Poly (ethylene oxide)-like Plasma Polymers Produced by Plasma-Assisted Vacuum Evaporation, Plasma Processes and Polymers 7(6) (2010) 445-458.

[122] D.J. Menzies, B. Cowie, C. Fong, J.S. Forsythe, T.R. Gengenbach, K.M. McLean, L. Puskar, M. Textor, L. Thomsen, M. Tobin, One-step method for generating PEG-like plasma polymer gradients: chemical characterization and analysis of protein interactions, Langmuir 26(17) (2010) 13987-13994.

[123] H.D. Hazrati, J.D. Whittle, K. Vasilev, A mechanistic study of the plasma polymerization of ethanol, Plasma Processes and Polymers 11(2) (2014) 149-157.

[124] A. Michelmore, P.M. Bryant, D.A. Steele, K. Vasilev, J.W. Bradley, R.D. Short, Role of positive ions in determining the deposition rate and film chemistry of continuous wave hexamethyl disiloxane plasmas, Langmuir 27(19) (2011) 11943-11950.

[125] A.J. Beck, F.R. Jones, R.D. Short, Plasma copolymerization as a route to the fabrication of new surfaces with controlled amounts of specific chemical functionality, Polymer 37(24) (1996) 5537-5539.

[126] R. M. France, R. D. Short, R. A. Dawson, S. Macneil, Attachment of human keratinocytes to plasma co-polymers of acrylic acid/octa-1,7-diene and allyl amine/octa-1,7diene, Journal of Materials Chemistry 8(1) (1998) 37-42. 
[127] R.M. France, R.D. Short, E. Duval, F.R. Jones, R.A. Dawson, S. MacNeil, Plasma copolymerization of allyl alcohol/1, 7-octadiene: surface characterization and attachment of human keratinocytes, Chemistry of materials 10(4) (1998) 1176-1183.

[128] R.M. France, R.D. Short, Plasma treatment of polymers: the effects of energy transfer from an argon plasma on the surface chemistry of polystyrene, and polypropylene. A highenergy resolution X-ray photoelectron spectroscopy study, Langmuir 14(17) (1998) 48274835.

[129] D. Haddow, R. France, R. Short, S. MacNeil, R. Dawson, G. Leggett, et al, Comparison of proliferation and growth of human keratinocytes on plasma copolymers of acrylic acid/1, 7octadiene and self-assembled monolayers, Journal of biomedical materials research $47(3)$ (1999) 379-387.

[130] M. Moustafa, C. Simpson, M. Glover, R.A. Dawson, S. Tesfaye, F. Creagh, et al, A new autologous keratinocyte dressing treatment for non-healing diabetic neuropathic foot ulcers, Diabetic medicine 21(7) (2004) 786-789.

[131] M. Moustafa, A.J. Bullock, F.M. Creagh, S. Heller, W. Jeffcoate, F. Game, et al, Randomized, controlled, single-blind study on use of autologous keratinocytes on a transfer dressing to treat nonhealing diabetic ulcers, (2007) 887-902.

[132] N. Zhu, R. Warner, C. Simpson, M. Glover, C. Hernon, J. Kelly, et al, Treatment of burns and chronic wounds using a new cell transfer dressing for delivery of autologous keratinocytes, European Journal of Plastic Surgery 28(5) (2005) 319-330.

[133] R. France, R. Short, R. Dawson, Attachment of human keratinocytes to plasma copolymers of acrylic acid/octa-1, 7-diene and allyl amine/octa-1, 7-diene, Journal of Materials Chemistry 8(1) (1998) 37-42.

[134] M. Moustafa, A. Bullock, F. Creagh, S. Heller, W. Jeffcoate, F. Game, et al, A randomised controlled single blind prospective pilot study on the use of autologous keratinocytes on a transfer dressing (Myskin) in the treatment of non-healing diabetic ulcers, Regen Med 2 (2007) 887-902.

[135] J. Freitag, D. Bates, R. Boyd, K. Shah, A. Barnard, L. Huguenin, et al, Mesenchymal stem cell therapy in the treatment of osteoarthritis: reparative pathways, safety and efficacy-a review, BMC musculoskeletal disorders 17(1) (2016) 230.

[136] B. D'Agostino, N. Sullo, D. Siniscalco, A. De Angelis, F. Rossi, Mesenchymal stem cell therapy for the treatment of chronic obstructive pulmonary disease, Expert opinion on biological therapy 10(5) (2010) 681-687.

[137] G. Li, F. Yu, T. Lei, H. Gao, P. Li, Y. Sun, et al, Bone marrow mesenchymal stem cell therapy in ischemic stroke: mechanisms of action and treatment optimization strategies, Neural Regeneration Research 11(6) (2016) 1015.

[138] A. Dulamea, Mesenchymal stem cells in multiple sclerosis-translation to clinical trials, $\mathbf{J}$ Med Life 8(1) (2015) 24-7.

[139] E.V. Badiavas, M. Abedi, J. Butmarc, V. Falanga, P. Quesenberry, Participation of bone marrow derived cells in cutaneous wound healing, Journal of cellular physiology 196(2) (2003) 245-250.

[140] N.G. Walker, A.R. Mistry, L.E. Smith, P.C. Eves, G. Tsaknakis, S. Forster, et al, A chemically defined carrier for the delivery of human mesenchymal stem/stromal cells to skin wounds, Tissue Engineering Part C: Methods 18(2) (2012) 143-155.

[141] D. Jiang, Y. Qi, N.G. Walker, A. Sindrilaru, A. Hainzl, M. Wlaschek, et al, K. Scharffetter-Kochanek, The effect of adipose tissue derived MSCs delivered by a chemically defined carrier on full-thickness cutaneous wound healing, Biomaterials 34(10) (2013) 25012515 . 
[142] G.T. Kirby, S.J. Mills, L. Vandenpoel, J. Pinxteren, A. Ting, R.D. Short, et al, Development of advanced dressings for the delivery of progenitor cells, ACS Applied Materials \& Interfaces (2017).

[143] G. Naughton, J. Mansbridge, G. Gentzkow, A metabolically active human dermal replacement for the treatment of diabetic foot ulcers, Artificial organs 21(11) (1997) 12031210.

[144] A.D. Celiz, J.G. Smith, R. Langer, D.G. Anderson, D.A. Winkler, D.A. Barrett, et al, Materials for stem cell factories of the future, Nature materials 13(6) (2014) 570-579.

[145] T. Ohki, M. Yamato, M. Ota, D. Murakami, R. Takagi, M. Kondo, et al, Endoscopic transplantation of human oral mucosal epithelial cell sheets-world's first case of regenerative medicine applied to endoscopic treatment, Gastrointestinal Endoscopy 69(5) (2009) AB253AB254.

[146] H. Shimizu, K. Ohashi, R. Utoh, K. Ise, M. Gotoh, M. Yamato, et al, Bioengineering of a functional sheet of islet cells for the treatment of diabetes mellitus, Biomaterials 30(30) (2009) 5943-5949. 